\title{
Pollution of urbanized territories by motor transport using the example of the Republic of North Ossetia - Alani
}

\author{
Vladislav Zaalishvili ${ }^{1, *}$, Aleksandr Kanukov ${ }^{2}$, and Ketevan Korbesova ${ }^{2}$ \\ ${ }^{1}$ North Ossetian State University after K.L. Khetagurov, 362025, Vatutina Street, 44-46, \\ Vladikavkaz, North Ossetia - Alania, Russian Federation \\ ${ }^{2}$ Geophysical Institute, Vladikavkaz Scientific Center, Russian Academy of Sciences, 362002, \\ Markova Street, 93a, Vladikavkaz, Russian Federation
}

\begin{abstract}
According to numerous studies, even with a relatively low level of exposure to adverse environmental factors, risk of health deterioration may occur. Both the amount of harmful emissions and their chemical composition directly affect the level of air pollution. The article considers the issues of environmental pollution of an urbanized area by automobile exhausts. The most polluted city is Vladikavkaz that is the capital of the Republic. There the main stationary sources of pollution are located and the largest number of vehicles is concentrated. The dynamics of increasing the number of vehicles in the city of Vladikavkaz over the past 10 years and a corresponding increase in harmful emissions from combustion products are shown. For the same period of time, the amount of emissions of harmful substances into the atmosphere from stationary sources has been considered in order to compare their contribution to total pollution compared to road transport. Based on the explorations, it is shown that the main source of pollution in terms of emissions in the Republic of North Ossetia-Alania is road transport. The number of vehicles is increasing year after year, amid a decrease in total emissions of pollutants from stationary sources.
\end{abstract}

\section{Introduction}

One of the most acute environmental problems of our time is environmental pollution, which leads to adverse effects on public health, especially in urban areas [1].

According to numerous studies, even with a relatively low level of exposure to adverse environmental factors, risk of health deterioration may occur [2]. The peculiarity of the influence of various harmful substances on the health of the population is that even for low concentrations, the harmful effect on the human body becomes significant with prolonged exposure [3].

Both the amount of emissions of harmful substances and their chemical composition directly affect the level of air pollution [4-7]. Besides, the significant factors are the height

\footnotetext{
*Corresponding author: cgi ras@mail.ru
} 
at which emissions occur, as well as the climatic conditions of the area, which determine the transfer, transformation and dispersion of the emitted harmful substances. Air pollution in the Republic of North Ossetia-Alania is regularly monitored as part of the state monitoring system for atmospheric air in a single system of state environmental monitoring of the Russian Federation. On the territory of the Republic, the largest contribution to environmental pollution is made by the non-ferrous metallurgy enterprises and motor vehicles. Obviously, the capital city of Vladikavkaz is the most polluted in the Republic. There the main stationary sources of pollution are located and the largest number of vehicles is concentrated. In rural areas of the Republic, there is a stable satisfactory state of atmospheric air due to the lack of large industrial enterprises and a large number of vehicles.

A huge amount of the following harmful substances is released into the atmosphere of the city: dust, sulfur and nitrogen dioxides, nitrogen and carbon oxides, which are considered to be the main ones, and, also, specific substances that are emitted by some industries and enterprises [8-10].

The condition of atmospheric air in Vladikavkaz and in the republic as a whole is unsatisfactory, although the total amount of pollutants in the atmosphere is much less than in large industrial centers of the country. According to the Federal Service for Supervision of Natural Resources, North Ossetia-Alania ranks 73rd (out of 85) in the rating for assessing emissions of air polluting substances by stationary and mobile sources in the regions of the Russian Federation in 2016 [11]. In terms of emissions, the republic is ahead of the Kamchatka Territory, the Republic of Crimea and Adygea, Magadan Oblast, the Republic of Karachay-Cherkessia, Kalmykia, Tyva, Altai, Ingushetia, the Jewish Autonomous Region, Chukotka Autonomous Region, Sevastopol.

More than 30 enterprises are located in the industrial hub of the city of Vladikavkaz, their activities are more or less related to air pollution. The largest enterprise in the Republic was OJSC "Electrozink", which throughout its existence has been actively polluting the environment. Although over the past decade, the enterprise has worked within a more acceptable framework for the city, having carried out a large-scale reconstruction of workshops and technologies. Since 2004, OJSC "Electrozink" implemented a transition to new technology for lead production. These measures allowed to reduce pollutant emissions by $74 \%$ (lead emissions decreased by $90 \%$, and sulfuric acid vapor by $68 \%$ ). At the end of 2016, by agreement between the republic government and OJSC "Electrozink", the closure of environmentally harmful lead production took place and now Electrozinc is in a state of conservation.

\section{Methods}

Motor vehicles make a much larger contribution to air pollution. Since most of the territory is occupied by mountain and foothill areas, road transport serves as the main type of transport in the internal economic relations of the republic [12-16]. The expansion of the rational use of road transport is typical for the republic.

The transport of small lots of high-value and perishable goods over long distances, a significant share of transportation over medium distances (300-1000 km) and almost all transportation over short distances (up to $100-150 \mathrm{~km}$ ) is covered by motor transport. The share of motor transport in the structure of passenger traffic is $64.9 \%$.

The number of vehicles in the city of Vladikavkaz over the past 20 years has more than doubled (Fig. 1). As can be seen from the graph, the growth of road transport is linear. Approximating this graph by a linear function, we can see a high correlation dependence of the number of vehicles on the year, with the approximation reliability value $\mathrm{R}^{2}=0.984$. The 
formula for the dependence of the number of vehicles on the year is: $y=7538 x+82794$, where $\mathrm{x}$ is the year minus 1994. According to the formula obtained, we can make a forecast for the number of vehicles in the Republic for several years ahead. So, for 2018, 2019 and 2020 , the expected number of vehicles will be 263706, 271244, and 278872 vehicles respectively. In 2017, cars emitted 81.1 thousand tons of pollutants into the atmosphere. The Republican fleet is obsolete, and therefore more harmful. The most polluted are the Promyshlennii and Iristonskii municipal districts of Vladikavkaz and areas near highways.

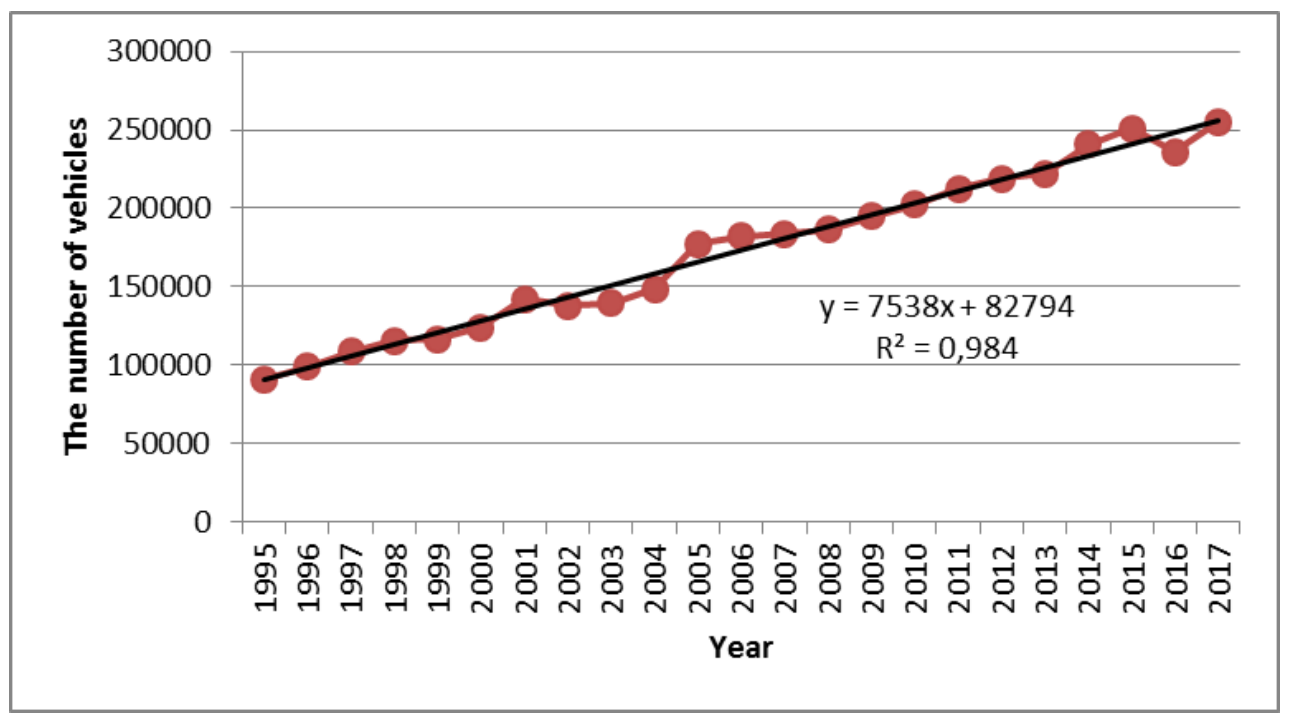

Fig. 1. The number of vehicles registered in the Republic of North Ossetia-Alania for the period 1995-2017.

According to the official portal of the Republic of North Ossetia-Alania http://alania.gov.ru, the length of public roads with a hard surface in the Republic is 2.3 thousand $\mathrm{km}$; the density is $286 \mathrm{~km}$ of roads per 1 thousand square $\mathrm{km}$ of territory. According to these indicators the Republic takes the 4th place among other regions, the first three places belong to Moscow, St. Petersburg and the Kaliningrad region. $257 \mathrm{~km}$ of federal and $2037 \mathrm{~km}$ of regional roads pass through the territory of the Republic. In total, the transport infrastructure is represented by five federal highways, and it also includes several railway junctions and the "Vladikavkaz" international airport.

The predominant harmful impurities in the exhaust gases of internal combustion engines are carbon and nitrogen oxides, aldehydes, hydrocarbons, and other substances. In the process of gasoline combustion, a number of chemical compounds are formed, consisting mainly of carbon monoxide, nitrogen oxides, hydrocarbons and lead compounds. Diesel engine exhaust contains soot, the presence of which leads to the formation of smog, unburned hydrocarbons, nitrogen oxides and sulfuric anhydride.

Wind speed contributes to the transport and dispersion of impurities, as the intensity of mixing of the air layers rises with increasing wind. In Vladikavkaz, the average annual wind speed is $2.5 \mathrm{~m} / \mathrm{sec}$., such a wind is characterized as very weak, and harmful polluting products emitted into the atmospheric air from industrial enterprises, vehicles and other objects are circulating for a long time in the surface layers of atmospheric air.

Solar radiation causes photochemical reactions in the atmosphere and the formation of various secondary products, which are often more toxic than substances coming from emission sources [17]. So, in the process of photochemical reactions in the atmosphere, sulfur dioxide is oxidized with the formation of sulfate aerosols. As a result of the 
photochemical effect on clear sunny days, photochemical smog is formed in polluted air. In fogs, the concentration of impurities can increase significantly. Smogs are associated with fogs, which retain high concentrations of harmful impurities for a long time [18-19]. Toxic substances, such as oxides of nitrogen, sulfur, carbon, deposited on droplets of fog, form acids, which, together with the inhaled air, penetrate the human respiratory tract. As a result, asthma attacks, lack of air, cardiovascular diseases may occur [20-25]. People with chronic diseases of the lungs, heart, elderly and children are especially sensitive to such adverse conditions.

Carbon monoxide and suspended solids for several years continue to be the main pollutants of atmospheric air in the city of Vladikavkaz.

\section{Results}

The laboratories of the Federal State Health Institution "Center for Hygiene and Epidemiology in the North Ossetia-Alania" of Rospotrebnadzor and the State Budget Institution "Center of Ecological Certification for Fuels and Lubricants" of the Ministry of Natural Resources of the North Ossetia-Alania conducted atmospheric air analysis on the main motorways of the city at 9 points, 6 of them in the city and 3 at the entrance to the city with simultaneous calculation of the number of passing vehicles. The results obtained allowed us to establish that there is a direct relationship between the flow of cars and air pollution, the most intense pollution was noted in the area of the "Druzhba" cinema and the Arkhonsky intersection. High dustiness and gas contamination in the absence of wind is noted. On the routes at the entrance to the city, a high concentration of sulfur dioxide (up to 4 maximum permissible concentrations) was revealed, which, in particular, can serve as an indirect sign of low-quality fuel use by heavy vehicles. The data obtained indicate a steady trend of increasing atmospheric air pollution from the increasing negative impact of vehicle emissions, which also has a bad effect on the health status of the population.

The total emissions of harmful substances from stationary sources into the atmosphere of the Republic of North Ossetia-Alania according to the generalized statistics of the 2-air supply statistics that were submitted by business entities to the Territorial Authority of Rosprirodnadzor for North Ossetia-Alania in 2017 amounted to 3.825 thousand tons, which is approximately $16 \%$ less than in the previous one (table 1 ).

In the area of industrial enterprises, the number of atmospheric air samples with excess MPC for 3 years decreased by $69.2 \%$. But, despite the ongoing work, the situation with air pollution in the capital of the Republic is far from satisfactory (Table 2).

Similarly to previous years, the largest number of enterprises polluting the atmosphere is located in the city of Vladikavkaz. Emissions from these enterprises amount to 2,448 thousand tons or about $64 \%$ of all emissions into the air from stationary sources of the Republic.

Figure 2 shows graphs of emissions from stationary sources and vehicles on the territory of North Ossetia-Alania for the period 1997-2015. As can be seen from the graphs presented, the main air pollutant in the North Ossetia-Alania is road transport, its effect is substantially higher than the emissions from stationary sources.

Over the course of 4 years, the share of atmospheric air samples with exceedance of hygiene standards increased by $36 \%$ on motorways in the residential development zone, due to an increase in suspended solids by $55.4 \%$; carbon monoxide - by $20 \%$. The share of non-standard samples of carbon monoxide in 2015 compared to 2014 increased by 1.5 times and amounted 7.2\% (table 3). 
Table 1. Dynamics of emissions from stationary sources in North Ossetia-Alania, thousand tons (State report on the condition and protection of the environment and natural resources of the Republic of North Ossetia-Alania in 2015-2017).

\begin{tabular}{|c|c|c|c|}
\hline & $\begin{array}{c}\text { Total released into the } \\
\text { atmosphere for 2015 }\end{array}$ & $\begin{array}{c}\text { Total released into } \\
\text { the atmosphere for } \\
2016\end{array}$ & $\begin{array}{c}\text { Total released into the } \\
\text { atmosphere for 2017 }\end{array}$ \\
\hline $\begin{array}{c}\text { Total emissions of } \\
\text { pollutants into the } \\
\text { atmosphere }\end{array}$ & 5.283 & 4.545 & 3.825 \\
\hline including: & 0.296 & 0.412 & 0.521 \\
\hline solid & 4.987 & 4.132 & 3.305 \\
\hline gaseous and liquid & 0.328 & 0.357 & 0.360 \\
\hline $\begin{array}{c}\text { of which: sulfur dioxide } \\
\text { carbon monoxide }\end{array}$ & 1.443 & 1.449 & 1.387 \\
\hline $\begin{array}{c}\text { nitric oxide (in terms of } \\
\text { NO2) }\end{array}$ & 0.268 & 0.253 & 0.288 \\
\hline $\begin{array}{c}\text { hydrocarbons (without } \\
\text { volatile organic } \\
\text { compounds) }\end{array}$ & 2.678 & 1.780 & 1.000 \\
\hline $\begin{array}{c}\text { volatile organic } \\
\text { compounds (VOC) }\end{array}$ & 0.196 & 0.197 & 0.181 \\
\hline other gaseous and liquid & 0.074 & 0.096 & 0.088 \\
\hline
\end{tabular}

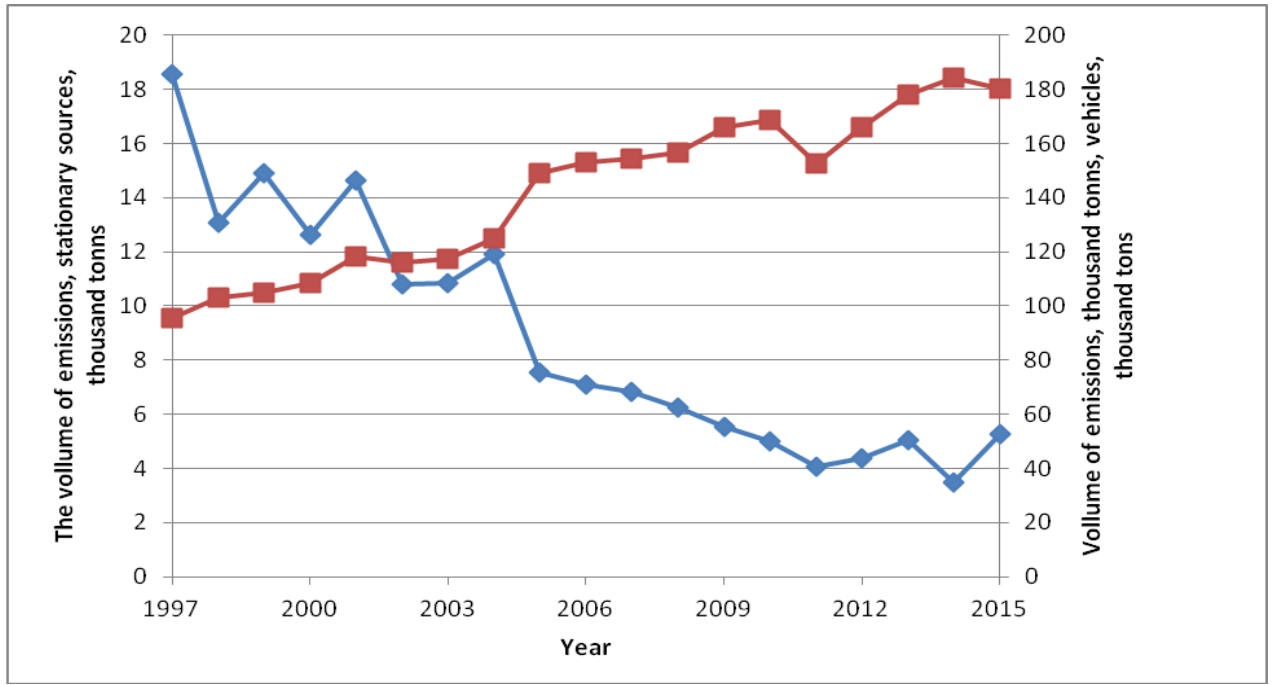

Fig. 2. Dynamics of emissions from stationary sources and vehicles on the territory of the Republic of North Ossetia-Alania for the period 1997-2015. Blue line in the diagram indicates the volume of emissions by stationary sources and red line by motor vehicles.

Table 2. The proportion of atmospheric air samples in excess of the MPC in residential areas near industrial enterprises in 2006 - 2015 (State report "On the state of the sanitary-epidemiological wellbeing of the population in the Republic of North Ossetia-Alania in 2006-2015"). 


\begin{tabular}{|c|c|c|c|c|c|c|c|}
\hline \multirow[b]{2}{*}{ 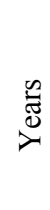 } & \multirow[b]{2}{*}{ Analysis Type } & \multicolumn{6}{|c|}{ Ingredients analyzed } \\
\hline & & $\begin{array}{l}\text { Suspended } \\
\text { solids }\end{array}$ & $\mathrm{SO}_{2}$ & $\mathrm{CO}$ & $\mathrm{NO}_{2}$ & $\begin{array}{l}\text { Heavy } \\
\text { metals } \\
\text { (lead) }\end{array}$ & Total \\
\hline \multirow{2}{*}{ ஜ̊̀ } & total analysis & 1164 & 781 & 960 & 1005 & 739 & 4800 \\
\hline & $\begin{array}{c}\text { with excess } \\
\text { MPC } \%\end{array}$ & 5.07 & - & 5.94 & 7.86 & - & 4.3 \\
\hline \multirow{2}{*}{ 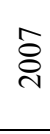 } & total analysis & 862 & 767 & 856 & 866 & 704 & 4153 \\
\hline & $\begin{array}{c}\text { with excess } \\
\text { MPC } \%\end{array}$ & 2.55 & 0.13 & 1.4 & 1.15 & - & 1.18 \\
\hline \multirow{2}{*}{$\stackrel{\infty}{8}$} & total analysis & 1371 & 1215 & 1251 & 1259 & 702 & 6011 \\
\hline & $\begin{array}{c}\text { with excess } \\
\text { MPC \% }\end{array}$ & 0.07 & 0.6 & 1.9 & 0.4 & 0 & 0.6 \\
\hline \multirow{2}{*}{ ڤे } & total analysis & 1141 & 1211 & 1021 & 1187 & 804 & 5844 \\
\hline & $\begin{array}{c}\text { with excess } \\
\text { MPC } \%\end{array}$ & 0.6 & 3.6 & 0.9 & 0.5 & 0 & 1.2 \\
\hline \multirow{2}{*}{$\stackrel{\circ}{\circ}$} & total analysis & 747 & 747 & 747 & 747 & 747 & 3735 \\
\hline & $\begin{array}{c}\text { with excess } \\
\text { MPC } \%\end{array}$ & 0.27 & 0.94 & - & 0.54 & - & 0.35 \\
\hline \multirow{2}{*}{$\overline{\check{c}}$} & total analysis & 1130 & 1034 & 1097 & 1169 & 432 & 4862 \\
\hline & $\begin{array}{c}\text { with excess } \\
\text { MPC \% }\end{array}$ & 0.4 & 0.2 & 2 & 0.17 & 0.7 & 1.3 \\
\hline \multirow{2}{*}{$\stackrel{ }{\overparen{1}}$} & total analysis & - & - & - & - & - & - \\
\hline & $\begin{array}{c}\text { with excess } \\
\text { MPC } \%\end{array}$ & - & - & - & - & - & - \\
\hline \multirow{2}{*}{$\stackrel{m}{\stackrel{2}{~}}$} & total analysis & 1000 & 978 & 1068 & 6 & 194 & 4531 \\
\hline & $\begin{array}{c}\text { with excess } \\
\text { MPC \% }\end{array}$ & 1.3 & 0 & 3.5 & 0 & 0 & 1.2 \\
\hline \multirow{2}{*}{$\stackrel{\text { d }}{\stackrel{d}{d}}$} & total analysis & 919 & 1107 & 1177 & 1152 & 123 & 4478 \\
\hline & $\begin{array}{c}\text { with excess } \\
\text { MPC } \%\end{array}$ & 1.3 & 0 & 1.4 & 0.4 & 0 & 1.4 \\
\hline \multirow{2}{*}{$\frac{n}{\stackrel{i}{c}}$} & total analysis & 1341 & 1210 & 1280 & 1296 & 161 & 5603 \\
\hline & $\begin{array}{c}\text { with excess } \\
\text { MPC \% }\end{array}$ & 2.2 & 0 & 6.2 & 0 & 0 & 2 \\
\hline
\end{tabular}

The laboratories of the Federal State Health Institution "Center for Hygiene and Epidemiology in the North Ossetia-Alania" of Rospotrebnadzor and the State Budget Institution "Center of Ecological Certification for Fuels and Lubricants" of the Ministry of Natural Resources of the North Ossetia-Alania conducted atmospheric air analysis on the main motorways of the city at 9 points, 6 of them in the city and 3 at the entrance to the city with simultaneous calculation of the number of passing vehicles. The results obtained allowed us to establish that there is a direct relationship between the flow of cars and air pollution, the most intense pollution was noted in the area of the "Druzhba" cinema and the 
Arkhonsky intersection. High dustiness and gas contamination in the absence of wind is noted. On the routes at the entrance to the city, a high concentration of sulfur dioxide (up to 4 maximum permissible concentrations) was revealed, which, in particular, can serve as an indirect sign of the use of low-quality fuel by heavy vehicles. The data obtained indicate a steady trend of increasing atmospheric air pollution from the increasing negative impact of vehicle emissions, which also has a bad effect on the health status of the population.

Table 3. The proportion of atmospheric air samples in excess of the maximum one-time MPC on motorways in the residential area for the period 2012 - 2015 (F-18 according to the State Budget Institution "Center of Ecological Certification for Fuels and Lubricants") (State report "On the state of the sanitary-epidemiological well-being of the population in the Republic of North Ossetia-Alania in 2007-2014").

\begin{tabular}{|c|c|c|c|c|c|c|}
\hline \multirow{2}{*}{ Year } & \multirow{2}{*}{ Type } & \multicolumn{5}{|c|}{ Analyzed ingredients } \\
\hline & & $\begin{array}{l}\text { Suspended } \\
\text { solids }\end{array}$ & $\begin{array}{c}\text { Sulfur } \\
\text { dioxide }\end{array}$ & $\begin{array}{c}\text { Carbon } \\
\text { monoxide }\end{array}$ & $\begin{array}{c}\text { Nitrogen } \\
\text { dioxide }\end{array}$ & Total \\
\hline \multirow[b]{2}{*}{2012} & $\begin{array}{c}\text { Analysis } \\
\text { total }\end{array}$ & 180 & 67 & 187 & 187 & 618 \\
\hline & $\begin{array}{c}\text { With } \\
\text { exceeding } \\
\text { MPC, \% }\end{array}$ & 0 & 0 & 3,7 & 0 & 1,1 \\
\hline \multirow[b]{2}{*}{2013} & $\begin{array}{c}\text { Analysis } \\
\text { total }\end{array}$ & 128 & 45 & 131 & 111 & 432 \\
\hline & $\begin{array}{c}\text { With } \\
\text { exceeding } \\
\text { MPC, \% }\end{array}$ & 1,6 & 0 & 6,1 & 2,7 & 3 \\
\hline \multirow[b]{2}{*}{2014} & $\begin{array}{c}\text { Analysis } \\
\text { total }\end{array}$ & 84 & 12 & 87 & 84 & 267 \\
\hline & $\begin{array}{c}\text { With } \\
\text { exceeding } \\
\text { MPC, \% }\end{array}$ & 11,9 & 0 & 4,6 & 0 & 5,2 \\
\hline \multirow[b]{2}{*}{2015} & $\begin{array}{c}\text { Analysis } \\
\text { total }\end{array}$ & 84 & 12 & 84 & 84 & 264 \\
\hline & $\begin{array}{c}\text { With } \\
\text { exceeding } \\
\text { MPC, } \%\end{array}$ & 14,3 & 0 & 7,2 & 0 & 6,8 \\
\hline
\end{tabular}

The laboratories of the Federal State Health Institution "Center for Hygiene and Epidemiology in the North Ossetia-Alania" of Rospotrebnadzor and the State Budget Institution "Center of Ecological Certification for Fuels and Lubricants" of the Ministry of Natural Resources of the North Ossetia-Alania conducted atmospheric air analysis on the main motorways of the city at 9 points, 6 of them in the city and 3 at the entrance to the city with simultaneous calculation of the number of passing vehicles (Figure 3). The results obtained allowed us to establish that there is a direct relationship between the flow of cars and air pollution, the most intense pollution was noted in the area of the "Druzhba" cinema and the Arkhonsky intersection. High dustiness and gas contamination in the absence of wind is noted. On the routes at the entrance to the city, a high concentration of sulfur dioxide (up to 4 maximum permissible concentrations) was revealed, which, in particular, 
can serve as an indirect sign of the use of low-quality fuel by heavy vehicles. The data obtained indicate a steady trend of increasing atmospheric air pollution from the increasing negative impact of vehicle emissions, which also has a bad effect on the health status of the population.

The number of complaints from the population about air pollution is constantly recorded on the "green line" of the Ministry of Natural Resources of the Republic of North Ossetia-Alania and in Rospotrebnadzor. In 2015, 37 complaints were registered, in 2016 43, in 2017 - 35, in 2018 - 14. In North Ossetia in 2017, an interdepartmental commission began to operate to evaluate the work of automated round-the-clock observation posts for monitoring the state of atmospheric air.

\section{Discussion of results}

Thus, we can conclude that the main source of pollution in the Republic of North OssetiaAlania is road transport, the number of which is increasing year after year, against the background of a decrease in total emissions of pollutants from stationary sources. It should be noted that, despite such a significant excess of emissions from vehicles over stationary sources, the damage to the environment cannot be evaluated directly for this indicator. Car emissions include carbon monoxide, volatile organic compounds and nitric oxide, accounting for almost $99 \%$ of total emissions, while their share in emissions from stationary sources is not so significant.

On the territory of the Republic, the largest contribution to environmental pollution is made by the operation of non-ferrous metallurgy enterprises and motor vehicles. More than 30 enterprises are located in the industrial hub of the city of Vladikavkaz, their operation is more or less related to air pollution.

A huge contribution to air pollution is made by motor vehicles, the amount of which in the city of Vladikavkaz over the past 20 years has more than doubled.

The predominant harmful impurities contained in the exhaust gases of internal combustion engines are carbon and nitrogen oxides, aldehydes, hydrocarbons, and other substances.

In the area of industrial enterprises, the number of atmospheric air samples with MPC excess for 3 years decreased by $69.2 \%$. But, despite the ongoing work, the situation with air pollution in the capital of the Republic is far from safe.

The main pollutant of atmospheric air in North Ossetia-Alania is road transport, its effect is substantially higher than the emissions from stationary sources.

It should be noted that, despite the significant excess of emissions from vehicles over stationary sources, the damage to the environment cannot be estimated directly from this indicator. Car emissions include carbon monoxide, volatile organic compounds and nitric oxide, accounting for almost $99 \%$ of total emissions, while their share in emissions from stationary sources is not so significant.

\section{References}

1. O. Beriev, V. Zaalishvili, Geology and Geophysics of Russian South 4, 47-56 (2015) doi: 10.23671/VNC.2015.4.55297

2. X. Dong, X. Zhao, F. Peng, D. Wang, Nature Research 10 (1), 479 (2020) doi: 10.1038/s41598-019-57385-9

3. L. Kebalova, Geographical Bulletin 3 (42), $71-77$ (2017) doi: 10.17072/2079-78772017-3-71-77 
4. V. Zaalishvili, O. Burdzieva, O. Beriev, A. Kanukov, M. Maysuradze, International Journal of GEOMATE 10 (1), 1693-1697 (2016) doi:10.21660/2016.19.5327

5. M. Hui, P. Shengyan, L. Shibin, et al., Environmental Pollution 261, 114089 (2020) doi: 10.1016/j.envpol.2020.114089

6. O. Burdzieva, V. Zaalishvili, S. Aiskhanov, et al., Advances in Engineering Research 182, 50-56 (2019) doi:10.2991/ciggg-18.2019.10

7. L. Hannah, Climate Change Biology, 261-275 (2011) doi: 10.1016/B978-0-12-374182$0.00012-1$

8. C. Damgaard, K. Irvine, Journal of Ecology, 2747 - 2760 (2019) doi: 10.1111/13652745.13200

9. C. Parmesan, Annual Review of Ecology, Evolution, and Systematics 37, 637-669, (2006) doi: 10.1146/annurev.ecolsys.37.091305.110100

10. K. Suding, Annual Review of Ecology, Evolution, and Systematics 42, 465-487, (2011) doi: 10.1146/annurev-ecolsys-102710-145115

11. V. Zaalishvili, I. Alborov, O. Burdzieva, Akustika 32, 211-215 (2019)

12. A. Luers, Global Environmental Change 15 (3), 214-223 (2005) doi: 10.1016/j.gloenvcha.2005.04.003

13. C. Polsky, R. Neff, B. Yarnal, Global Environmental Change 17 (3-4), 472-485 (2007) doi: 10.1016/j.gloenvcha.2007.01.005

14. L. Mcfadden, Environmental Hazards $9 \quad$ (3), 217-221 (2010) doi:10.3763/ehaz.2010.0055

15. P. Darbre: Environmental Contaminants, Encyclopedia of Food Safety, 323-331 (2014) doi: 10.1016/b978-0-12-378612-8.00196-7

16. A. Makosko, A. Matesheva, V. Aksenov, V. Apatsev, IOP Conference Series: Earth and Environmental Science (2019) doi:10.1088/1755-1315/231/1/012032

17. O. Burdzieva, V. Zaalishvili, T. Zaks, Akustika 32, 206-210 (2019)

18. J. Qian, E. Akçay, Nature Ecology \& Evolution 4, 356-365 (2020) doi: 10.1038/s41559-020-1121-x

19. H. De Kort B. Panis K. Helsen R. Douzet S.B. Janssens ay O. Honn, Journal of Ecology (2020) doi: 10.1111/1365-2745.13365

20. T. Zaks, A. Kanukov, I. Maliev, et al., Geology and Geophysics Russian South 4, 6874 (2016) doi: 10.23671/VNC.2016.4.20900

21. S. Saha, Research Data Archive at the National Center for Atmospheric Research: Computational and Information Systems Lab. (2010) doi:10.5065/ D6513W89

22. Q. Hai-Bo, Z. Jian-Ming, L. Zhi-Qing, et al., Environmental Pollution 225, 361- 369 (2017) doi: 10.1016/j.envpol.2017.02.062

23. M. Kuziakina, D. Gura, D. Zverok, E3S Web of Conferences 138, 02004 (2019). DOI: $10.1051 / \mathrm{e} 3 \operatorname{sconf} / 201913802004$

24. Y.V. Dubenko, D.A. Gura, E.E. Dyshkant, International Multi-Conference on Industrial Engineering and Modern Technologies, FarEastCon 2019, 8934179 (2019). DOI: 10.1109/FarEastCon.2019.8934179

25. M. Kuzyakina, D. Gura, A. Sekisov, N. Granik, Advances in Intelligent Systems and Computing 983, 403-416 (2019). DOI: 10.1007/978-3-030-19868-8_41 